\title{
IMPLEMENTASI METODE QUALITY FUNCTION DEPLOYMENT (QFD) DALAM MENGANALISIS KUALITAS PELAYANAN PADA BENGKEL POLITEKNIK
}

\author{
Arianti Kusumawardhani ${ }^{1}$, Shafiq Nurdin ${ }^{2}$ \\ TeknikMesin \\ Politeknik Unisma Malang, Malang, Indonesia \\ e-mail : ${ }^{1}$ arianti@poltekunisma.ac.id, ${ }^{2}$ shafiq@poltekunisma.ac.id \\ Diterima: 28 September 2018. Disetujui : 19 Oktober 2018. Dipublikasikan : 10 Desember 2018 \\ (C)2018 -TESJ Fakultas Teknik Universitas Maarif Hasyim Latif. Ini adalah artikel dengan \\ akses terbuka di bawah lisensi CC BY 4.0 (https://creativecommons.org/licenses/by/4.0/)
}

\begin{abstract}
ABSTRAK
Penelitian ini menganalisis tentang kualitas pelayanan bengkel di Politeknik Unisma Malang (PUM), dengan tujuan untuk memperbaiki pelayanan di bengkel. Caranya adalah dengan menggunakan metode Servqual yang diintegrasikan dengan metode QualityFunction Deployment untuk mengetahui persepsi dan harapan mahasiswa terhadap pelayanan yang telah diberikan selama ini. Setelah diketahui atribut yang diinginkan mahasiswa terhadap pelayanan bengkel maka akan menjadi voice of customer dan diolah di House of Quality untuk dapat menghasilkan prioritas rekomendasi perbaikan yang sesuai dengan kebutuhan pihak bengkel. Hasil dari penelitian ini berdasarkan hasil uji validitas dan reliabilitas terdapat 18 atribut yang dinyatakan valid dan reliabel yang selanjutnya dibuat kuesioner kemudian disebarkan ke pihak pengguna bengkel (mahasiswa). Dari hasil matriks House of Quality, ada beberapa prioritas pelayanan bengkel PUM yang perlu dilakukan berdasarkan atribut jasa pelayanan yang diharapkan oleh mahasiswa adalah : ketepatan waktu dan kesesuaian jadwal, asisten bengkel harus mempunyai keahlian atau pengalaman di bengkel, memberikan pelatihan tambahan untuk asisten bengkel, penilaian terbuka dan mudah diakses, disediakan kotak kritik dan saran, dibuatkan form peminjaman alat, peningkatan kemampuan dan daya tanggap asisten bengkel, pembelian alat dan bahan untuk praktik, disediakan tempat sampah di bengkel, disediakan alat-alat kebersihan di bengkel, mahasiswa diwajibkan untuk membersihkan bengkel setelah selesai praktik, ruangan bengkel dengan pencahayaan dan sirkulasi udara yang baik, penilaian performa kerja (per tahun).
\end{abstract}

Kata kunci:service quality, quality function deployment, house of quality

\section{PENDAHULUAN}

Perguruan tinggi adalah penyelenggara pendidikan tinggi, yang merupakan komponen sistem pendidikan formal nasional di negara masing-masing. Disamping mengemban tugas universal, sebuah perguruan tinggi juga mengemban tugas nasional. Tugas universal berupa mengembangkan kecerdasan anak didik sebagai insan ilmu pengetahuan dan kemanusiaan. Tugas nasional berupa mengembangkan keterampilan anak didik sebagai insan teknologi dan pengabdi masyarakat bangsanya. Di dalam subsistem pendidikan tinggi, perguruan tinggi dapat diselenggarakan oleh pemerintah yang disebut Perguruan Tinggi Negeri (PTN) maupun yang dikelola masyarakat yangdikenal dengan Perguruan Tinggi Swasta (PTS).

Persaingan di dalam dunia pendidikan khususnya pada peguruan tinggi swasta saat ini semakin ketat. Hal ini menuntut adanya perhatian lebih pada peningkatan kualitas jasa pendidikan baik dari segi pelayanan administrasi maupun fasilitas yang ditawarkan kepada konsumen (Rheza, 2014). Konsumen yang menggunakan jasa pendidikan adalah merupakan sekelompok orang yang memiliki kepentingan baik langsung maupun tidak langsung atas pelaksanaan pendidikan maupun hasil-hasilnya yang meliputi mahasiswa, staf lembaga pendidikan, masyarakat dan pemerintah. Setiap pihak yang berkepentingan dalam suatu institusi tersebut harus dapat dipenuhi kebutuhannya agara lembaga pendidikan dapat bersaing dan bertahan di dalam persaingan yang ketat (Baheramsyah, 2012). Selanjutnya, (Widarman, 2016) menerangkan bahwa untuk dapat bertahan dan bersaing sebuah perusahaan atau lembaga penyelenggara pendidikan tentunya harus dapat menciptakan Competitive Advantage. Salah satu bentuk Competitive Advantage adalah memberikan pelayanan berkualitas dalam penyelenggaraan pendidikan. Oleh karena itu, lembaga pendidikan perlu mendapat pengaturan dan standarisasi untuk memenangkan kompetisi 
dengan peningkatan mutu, kualitas serta pelayanan yang nantinya akan berujung pada kepuasan konsumen. Namun apabila kualitas dan pelayanan tidak mendapatkan perhatian lebih, tentunya akan memberikan imbas pada hilangnya kepercayaan konsumen pada lembaga.

Hidayat (Hidayat, 2012) berpendapat bahwa perkembangan dunia pendidikan yang begitu kompetitif, menuntut perguruan tinggi mampu menyelenggarakan pendidikan secara profesional sehingga sesuai dengan kebutuhan pasar kerja. Pendirian tempat pendidikan yang berorientasi juga telah dikembangkan sesuai dengan kebutuhan industri. Perkembangan tersebut dapat dilihat dari pendirian lembaga pendidikan yaitu Politeknik Unisma Malang.

Politeknik Unisma Malang merupakan salah satu perguruan tinggi swasta Program Diploma III (D-3) di Kota Malang yang memiliki dua program studi antara lain Teknik Mesin dan Teknik Listrik. Untuk program studi teknik mesin, institusi ini memiliki beberapa bengkel sebagai fasilitas penunjang pekuliahan khususnya bidang keahlian. Bengkel ini digunakan oleh mahasiswa politeknik dalam pelaksanaan praktik untuk meningkatkan keahlian dan kompetensi di bidang teknik mesin. Namun, kondisi dari bengkel tersebut masih belum diimbangi dengan peningkatan pelayanan dan kualitas bengkel yang ada.

Berdasarkan observasi dan wawancara dengan beberapa mahasiswa dan kepala bengkel terdapat beberapa keluhan terhadap pelayanan yang ada pada bengkel tersebut, antara lain: peralatan yang digunakan masih lama dan belum lengkap, tempat yang kurang bersih, sistem administrasi peminjaman peralatan perlengkapan praktik yang lama, mesin serta peralatan masih belum tertata dengan rapi, staf pengelola bengkel yang kurang kompeten dan responsif. Ketidakpuasan mahasiswa ini tentunya akan memberikan dampak negatif terhadap kepercayaan kualitas jasa yang diberikan Prodi Teknik Mesin pada Politeknik Unisma Malang khususnya terhadap fasilitas bengkel praktik. Oleh karena itu, kepuasan konsumen yang dalam hal ini adalah mahasiswa perlu mendapat perhatian yang lebih supaya dapat memberikan pelayanan serta kualitas bengkel sebagai tempat praktik yang sesuai dengan keinginan dan harapan dari mahasiswa untuk meningkatkan keahlian dan kompetensi.

Salah satu metode yang dapat digunakan untuk mengetahui keinginan dari konsumen ini adalah metode Quality Function Deployment (QFD). Pada bidang pengembangan industri, Metode Quality Function Deployment (QFD) menjadi salah satu metode terstruktur untuk menentukan Voice of the Customer (VOC) serta merancang dan mengembangkan suatu produk baru untuk memenuhi kebutuhan yang diinginkan oleh konsumen (Jaiswal, 2012). Pada penelitian ini, Metode QFD akan digunakan untuk mengetahui keinginan mahasiswa sebagai konsumen terhadap pelayanan dan kualitas bengkel praktikum Politeknik Unisma Malang.

\section{METODE PENELITIAN}

Jenis penelitian ini adalah penelitian deskriptif. Penelitian deskriptif bertujuan untuk mengumpulkan data atau informasi untuk disusun, dijelaskan dan dianalisis. Di sini menggunakan metode servqual untuk menggambarkan kesenjangan antara jasa yang diharapkan dengan jasa yang telah dirasakan serta metode Quality Function Deployment untuk menggambarkan pengembangan jasa yang akan direkomendasikan sesuai dengan kebutuhan konsumen. Pada penelitian deskriptif ini, pengumpulan data didapatkan dari penelitian kepustakaan dan penelitian lapangan yang berupa wawancara, kuesioner ataupun pengamatan langsung terhadap keadaan yang sebenarnya dalam perusahaan.

\section{HASIL DAN PEMBAHASAN}

\section{Pengumpulan Data Konsumen/Mahasiswa}

Dari hasil diskusi dan wawancara langsung dengan para mahasiswa tersebut dapat diambil beberapa atribut sebagaimana pada Tabel 1.

Dari atribut-atribut pada Tabel 1, kemudian dibuat kuesioner dan disebarkan kepada 30 orang responden, hal tersebut sesuai dengan syarat kecukupan data yaitu minimal 30 data.

\section{Pengumpulan Data Pihak Politeknik}

Data dari pihak politeknik diperoleh melalui wawancara dan observasi. Adapun data yang diperoleh sesuai dengan metode pengolahan yang akan digunakan yaitu : Nilai Target, Sales Point dan Parameter Teknik.

\section{Teknik Analisis Data}

\section{Uji Validitas dan Reliabilitas}

Uji validitas dalam penelitian ini menggunakan Microsoft Excell. Uji signifikansi dilakukan dengan membandingkan nilai $r$ hitung dengan rtable untuk degree of freedom $(d f)=n-2$, dalam hal ini $n$ adalah jumlah sampel, pada kasus ini jumlah sampel $(n)=30$ dan besarnya $d f$ dapat dihitung $30-2=28$ dengan $d f=28$ dan alpha 0,05 didapat rtable $=0.3610$.

Berdasarkan hasil perhitungan, ada dua atribut yang dinyatakan tidak valid, yaitu atribut no. 10 dan no. 15 (Tabel 1). Maka kuesioner dibuat dengan menghilangkan kedua atribut tersebut. 
Tabel 1. Atribut keinginan mahasiswa terhadap pelayanan bengkel PUM

\begin{tabular}{clc}
\hline No & \multicolumn{1}{c}{ Atribut } & Dimensi \\
\hline 1 & Jadwal praktik sesuai dengan waktu & Keandalan \\
\hline 2 & Asisten bengkel membantu dalam menyelesaikan masalah & Keandalan \\
\hline 3 & Penilaian didokumentasikan dengan baik & Keandalan \\
\hline 4 & Penilaian akurat dan terbuka bagi praktikan & Keandalan \\
\hline 5 & Asisten bengkel mudah ditemui dan tepat waktu & Daya Tanggap \\
\hline 6 & Asisten bengkel memberikan informasi yang tepat mengenai tata cara dan & Daya Tanggap \\
\hline 7 & penilaian praktik & Daya Tanggap \\
\hline 8 & Administrasi penggunaan fasilitas bengkel mudah dan transparan & Daya Tanggap \\
\hline 9 & Asisten bengkel memiliki pengetahuan dan mampu menjawab praktikan & Jaminan \\
\hline 10 & Asisten bengkel sopan dan ramah kepada praktikan & Jaminan \\
\hline 11 & Asisten bengkel dapat menciptakan rasa aman kepada pratikan selama praktik & Jaminan \\
\hline 12 & berlangsung & Jaminan \\
\hline & memberikan pelayanan kepada pengguna layanan (mahasiswa) & Empati \\
\hline 13 & Asisten bengkel memberikan perhatian kepda praktikan & Empati \\
\hline 14 & Asisten bengkel sungguh-sungguh mengutamakan kepentingan praktikan & Empati \\
\hline 15 & Asisten bengkel memahami kebutuhan praktikan & Empati \\
\hline 16 & Jam operasional bengkel memberikan kemudahan bagi praktikan & Bukti Fisik \\
\hline 17 & Bengkel memiliki peralatan yang cukup lengkap dan mutakhir & Bukti Fisik \\
\hline 18 & Ruangan bengkel cukup luas, nyaman, dan bersih & Bukti Fisik \\
\hline 19 & Jumlah peralatan di bengkel cukup bagi pengguna layanan & Bukti Fisik \\
\hline 20 & Asisten bengkel berpenampilan rapi dan profesional &
\end{tabular}

Tabel 2. Tingkat kepentingan atribut

\begin{tabular}{llll}
\hline No & \multicolumn{1}{c}{ Dimensi } & \multicolumn{1}{c}{ Atribut } & $\begin{array}{c}\text { Tingkat } \\
\text { Kepentingan }\end{array}$ \\
\hline 1 & Keandalan & Jadwal praktik sesuai dengan waktu & 4 \\
\hline 2 & Keandalan & Asisten bengkel membantu dalam menyelesaikan masalah & 4 \\
\hline 3 & Keandalan & Penilaian didokumentasikan dengan baik & 4 \\
\hline 4 & Keandalan & Penilaian akurat dan terbuka bagi praktikan & 4 \\
\hline 5 & Daya Tanggap & Asisten bengkel mudah ditemui dan tepat waktu & 4 \\
\hline 6 & Daya Tanggap & Asisten bengkel memberikan informasi yang tepat mengenai tata cara dan & 4 \\
\hline 7 & Daya Tanggap & Di bengkel telah tersedia kotak pengaduan/keluhan & 1 \\
\hline 8 & Daya Tanggap & Administrasi penggunaan fasilitas bengkel mudah dan transparan & 4 \\
\hline 9 & Jaminan & Asisten bengkel memiliki pengetahuan dan mampu menjawab praktikan & 4 \\
\hline 10 & Jaminan & Asisten bengkel dapat menciptakan rasa aman kepada pratikan selama & 4 \\
\hline 11 & Jaminan & Asisten bengkel mempunyai ketrampilan yang sangat memuaskan dalam & 4 \\
\hline 12 & Empati & Asisten bengkel memberikan perhatian kepda praktikan & 4 \\
\hline 13 & Empati & Asisten bengkel sungguh-sungguh mengutamakan kepentingan praktikan & 4 \\
\hline 14 & Empati & Jam operasional bengkel memberikan kemudahan bagi praktikan & 4 \\
\hline 15 & Bukti Fisik & Bengkel memiliki peralatan yang cukup lengkap dan mutakhir & 3 \\
\hline 16 & Bukti Fisik & Ruangan bengkel cukup luas, nyaman, dan bersih & 3 \\
\hline 17 & Bukti Fisik & Jumlah peralatan di bengkel cukup bagi pengguna layanan & 3 \\
\hline 18 & Bukti Fisik & Asisten bengkel berpenampilan rapi dan profesional & \\
\hline
\end{tabular}

Dan dari semua atribut yang valid tersebut, semuanya reliabel.

\section{Pengolahan Data Quality Function of Deployment (QFD)}

a. Matriks House of Quality (HOQ)

Tahap pertama dalam penelitian yaitu mencari atribut-atribut yang diinginkan oleh para konsumen dalam hal ini mahasiswa Teknik Mesin di PUM terhadap pelayanan bengkel yang diberikan dengan sharing dan berdiskusi. Dari hasil diskusi didapat beberapa atribut harapan kebutuhan atau kepentingan terhadap pelayanan bengkel di PUM. Dan dari 20 atribut yang ada diuji validitas dan reliablenya akhirnya didapat 18 atribut yang dijadikan kuesioner.

\section{b.Planning Matriks}

1) Menentukan Tingkat Kepentingan Konsumen (Importance to Customer) Dari hasil penyebaran kuesioner maka dapat dihitung tingkat kepentingan konsumen dengan melihat skala pengukuran yang memiliki nilai terbanyak dari pengisian tiap-tiap kebutuhan konsumen. Maka hasil perhitungan dengan skala Likert yang dimodifikasikan sebagai berikut :

$$
\begin{aligned}
& 1=\text { Sangat Tidak Penting (STP) } \\
& 2=\text { Tidak Penting (TP) } \\
& 3=\text { Cukup Penting (CP) } \\
& 4=\text { Penting (P) } \\
& 5=\text { = Sangat Penting (SP) }
\end{aligned}
$$

Sehingga hasil dapat dilihat pada Tabel 2.

2) Menentukan tingkat kepuasan (lihat Tabel 3) 
3) Penentuan nilai target (Goal) (lihat Tabel 4)

4) Rasio Perbaikan (Improvement Ratio) (lihat Tabel 5)

5) Penentuan Titik Jual Point (lihat Tabel 6)

6) Raw Weight (lihat Tabel 7)

7) Normalized Raw Weight (lihat Tabel 8)

8) Penyusunan Kepentingan Teknik (Respon Teknis)

Pada tahap ini pihak bengkel akan memberikan atau memunculkan solusisolusi untuk memenuhi keinginan pelanggan. Atau dengan kata lain, solusi yang ditawarkan merupakan respon (secara teknis) terhadap voice of the customer untuk dapat memenuhi kepuasan pelanggan. Respon teknis yang didapatkan menggambarkan kemampuan teknis dari bengkel PUM yang mampu merespon keinginan pelanggan seperti pada Tabel 9.

9) Menentukan Prioritas

Penentuan ini menunjukkan prioritas yang akan dikembangkan lebih dulu berdasarkan kepentingan teknik. Penentuan prioritas dapat dihitung dengan rumus berikut :

Contribution $=($ Numerical Value. Numerical Raw Weight $)$

Hasil perhitungan bisa dilihat pada Tabel 10.

Tabel 3. Tingkat kepuasan

\begin{tabular}{|c|c|c|c|}
\hline No & Dimensi & Atribut & $\begin{array}{c}\text { Nilai } \\
\text { Kepuasan }\end{array}$ \\
\hline & Keandalan & Jadwal praktik sesuai dengan waktu & 3,53 \\
\hline & Keandalan & Asisten bengkel membantu dalam menyelesaikan masalah & 3,73 \\
\hline & Keandalan & Penilaian didokumentasikan dengan baik & 3,96 \\
\hline & Keandalan & Penilaian akurat dan terbuka bagi praktikan & 4,07 \\
\hline & Daya Tanggap & Asisten bengkel mudah ditemui dan tepat waktu & 3,67 \\
\hline & Daya Tanggap & $\begin{array}{l}\text { Asisten bengkel memberikan informasi yang tepat mengenai tata cara } \\
\text { dan penilaian praktik }\end{array}$ & 3,87 \\
\hline & Daya Tanggap & Di bengkel telah tersedia kotak pengaduan/keluhan & 2,67 \\
\hline & Daya Tanggap & Administrasi penggunaan fasilitas bengkel mudah dan transparan & 3,8 \\
\hline & Jaminan & Asisten bengkel memiliki pengetahuan dan mampu menjawab praktikan & 3,53 \\
\hline & Jaminan & $\begin{array}{l}\text { Asisten bengkel dapat menciptakan rasa aman kepada pratikan selama } \\
\text { praktik berlangsung }\end{array}$ & 4,03 \\
\hline & Jaminan & $\begin{array}{l}\text { Asisten bengkel mempunyai ketrampilan yang sangat memuaskan dalam } \\
\text { memberikan pelayanan kepada pengguna layanan (mahasiswa) }\end{array}$ & 3,77 \\
\hline & Empati & Asisten bengkel memberikan perhatian kepda praktikan & 3,67 \\
\hline & Empati & Asisten bengkel sungguh-sungguh mengutamakan kepentingan praktikan & 3,83 \\
\hline & Empati & Jam operasional bengkel memberikan kemudahan bagi praktikan & 3,63 \\
\hline & Bukti Fisik & Bengkel memiliki peralatan yang cukup lengkap dan mutakhir & 2,7 \\
\hline & Bukti Fisik & Ruangan bengkel cukup luas, nyaman, dan bersih & 3,07 \\
\hline & Bukti Fisik & Jumlah peralatan di bengkel cukup bagi pengguna layanan & 2,76 \\
\hline & Bukti Fisik & Asisten bengkel berpenampilan rapi dan profesional & 3,13 \\
\hline
\end{tabular}

Tabel 4. Nilai target

\begin{tabular}{clc}
\hline No & \multicolumn{1}{c}{ Kebutuhan Konsumen } & $\begin{array}{c}\text { Nilai Target } \\
\text { (GOAL) }\end{array}$ \\
\hline 1 & Jadwal praktik sesuai dengan waktu & 5 \\
\hline 2 & Asisten bengkel membantu dalam menyelesaikan masalah & 5 \\
\hline 3 & Penilaian didokumentasikan dengan baik & 5 \\
\hline 4 & Penilaian akurat dan terbuka bagi praktikan & 5 \\
\hline 5 & Asisten bengkel mudah ditemui dan tepat waktu & 4 \\
\hline 6 & Asisten bengkel memberikan informasi yang tepat mengenai tata cara dan & 4 \\
\hline 7 & penilaian praktik & 5 \\
\hline 8 & Administrasi penggunaan fasilitas bengkel mudah dan transparan & 5 \\
\hline 9 & Asisten bengkel memiliki pengetahuan dan mampu menjawab praktikan & 4 \\
\hline 10 & Asisten bengkel dapat menciptakan rasa aman kepada pratikan selama praktik & 5 \\
\hline & berlangsung & 4 \\
\hline 11 & Asisten bengkel mempunyai ketrampilan yang sangat memuaskan dalam & 5 \\
\hline 12 & memberikan pelayanan kepada pengguna layanan (mahasiswa) & 5 \\
\hline 13 & Asisten bengkel sungguh-sungguh mengutamakan kepentingan praktikan & 4 \\
\hline 14 & Jam operasional bengkel memberikan kemudahan bagi praktikan & 4 \\
\hline 15 & Bengkel memiliki peralatan yang cukup lengkap dan mutakhir & 4 \\
\hline 16 & Ruangan bengkel cukup luas, nyaman, dan bersih & 4 \\
\hline 17 & Jumlah peralatan di bengkel cukup bagi pengguna layanan & 5 \\
\hline 18 & Asisten bengkel berpenampilan rapi dan profesional & \\
\hline & & \\
\hline
\end{tabular}


Tabel 5. Rasio perbaikan

No

Kebutuhan Konsumen

Ratio

Perbaikan

1 Jadwal praktik sesuai dengan waktu

2 Asisten bengkel membantu dalam menyelesaikan masalah

3 Penilaian didokumentasikan dengan baik

4 Penilaian akurat dan terbuka bagi praktikan

5 Asisten bengkel mudah ditemui dan tepat waktu

6 Asisten bengkel memberikan informasi yang tepat mengenai tata cara dan penilaian praktik

7 Di bengkel telah tersedia kotak pengaduan/keluhan

8 Administrasi penggunaan fasilitas bengkel mudah dan transparan

9 Asisten bengkel memiliki pengetahuan dan mampu menjawab praktikan

10 Asisten bengkel dapat menciptakan rasa aman kepada pratikan selama praktik berlangsung

11 Asisten bengkel mempunyai ketrampilan yang sangat memuaskan dalam memberikan pelayanan kepada pengguna layanan (mahasiswa)

12 Asisten bengkel memberikan perhatian kepda praktikan

\begin{tabular}{ll}
13 & Asisten bengkel sungguh-sungguh mengutamakan kepentingan praktikan \\
\hline 14 & 1,305
\end{tabular}

\begin{tabular}{ll}
14 & Jam operasional bengkel memberikan kemudahan bagi praktikan \\
\hline
\end{tabular}

15 Bengkel memiliki peralatan yang cukup lengkap dan mutakhir $1,1,481$

16 Ruangan bengkel cukup luas, nyaman, dan bersih

17 Jumlah peralatan di bengkel cukup bagi pengguna layanan

18 Asisten bengkel berpenampilan rapi dan profesional

1,303

1,449

1,597

Tabel 6. Titik jual

Kebutuhan Konsumen

Titik Jual

$1 \quad$ Jadwal praktik sesuai dengan waktu 1,2

\begin{tabular}{ccc}
\hline 2 & Asisten bengkel membantu dalam menyelesaikan masalah & 1,5 \\
\hline
\end{tabular}

3 Penilaian didokumentasikan dengan baik 1

4 Penilaian akurat dan terbuka bagi praktikan $\quad 1,2$

$\begin{array}{lll}4 & \text { Asisten bengkel mudah ditemui dan tepat waktu } & 1,5\end{array}$

\begin{tabular}{ccc}
\hline 6 & Asisten bengkel memberikan informasi yang tepat mengenai tata cara dan penilaian praktik & 1,2 \\
\hline 7 & Dibeng
\end{tabular}

$\begin{array}{lll}7 & \text { Di bengkel telah tersedia kotak pengaduan/keluhan } & 1,2\end{array}$

8 Administrasi penggunaan fasilitas bengkel mudah dan transparan

9 Asisten bengkel memiliki pengetahuan dan mampu menjawab praktikan

10 Asisten bengkel dapat menciptakan rasa aman kepada pratikan selama praktik berlangsung $\quad 1,5$

11 Asisten bengkel mempunyai ketrampilan yang sangat memuaskan dalam memberikan pelayanan kepada $\quad 1,5$ pengguna layanan (mahasiswa)

12 Asisten bengkel memberikan perhatian kepda praktikan

1,2

13 Asisten bengkel sungguh-sungguh mengutamakan kepentingan praktikan

14 Jam operasional bengkel memberikan kemudahan bagi praktikan

15 Bengkel memiliki peralatan yang cukup lengkap dan mutakhir

16 Ruangan bengkel cukup luas, nyaman, dan bersih

17 Jumlah peralatan di bengkel cukup bagi pengguna layanan

18 Asisten bengkel berpenampilan rapi dan profesional

Tabel 7. Raw weight

No

Kebutuhan Konsumen

Raw

1 Jadwal praktik sesuai dengan waktu

2 Asisten bengkel membantu dalam menyelesaikan masalah

3 Penilaian didokumentasikan dengan baik

4 Penilaian akurat dan terbuka bagi praktikan

5 Asisten bengkel mudah ditemui dan tepat waktu

6 Asisten bengkel memberikan informasi yang tepat mengenai tata cara dan penilaian praktik

7 Di bengkel telah tersedia kotak pengaduan/keluhan

8 Administrasi penggunaan fasilitas bengkel mudah dan transparan

9 Asisten bengkel memiliki pengetahuan dan mampu menjawab praktikan

Asisten bengkel mempunyai ketrampilan yang sangat memuaskan dalam memberikan pelayanan kepada pengguna layanan (mahasiswa)

12 Asisten bengkel memberikan perhatian kepda praktikan

13 Asisten bengkel sungguh-sungguh mengutamakan kepentingan praktikan

14 Jam operasional bengkel memberikan kemudahan bagi praktikan

15 Bengkel memiliki peralatan yang cukup lengkap dan mutakhir

16 Ruangan bengkel cukup luas, nyaman, dan bersih

17 Jumlah peralatan di bengkel cukup bagi pengguna layanan

18 Asisten bengkel berpenampilan rapi dan profesional 


\section{PENUTUP}

Atribut jasa pelayanan bengkel PUM yang dianggap penting oleh mahasiswa berdasarkan tingkat kepentingan atribut adalah : jadwal praktik sesuai waktu,asisten bengkel membantu dalam menyelesaikan masalah, penilaian didokumentasikan dengan baik, penilaian akurat dan terbuka bagi praktikan, asisten bengkel mudah ditemui dan tepat waktu, asisten bengkel memberikan informasi yang tepat mengenai tata cara dan penilaian praktik, administrasi penggunaan fasilitas bengkel mudah dan transparan, asisten bengkel memiliki pengetahuan dan mampu menjawab praktikan, asisten bengkel dapat menciptakan rasa aman kepada pratikan selama praktik berlangsung, asisten bengkel mempunyai ketrampilan yang sangat memuaskan dalam memberikan pelayanan kepada pengguna layanan (mahasiswa), asisten bengkel memberikan perhatian kepada praktikan, asisten bengkel sungguhsungguh mengutamakan kepentingan praktikan, jam operasional bengkel memberikan kemudahan bagi praktikan.

Prioritas pengembangan pelayanan bengkel PUM berdasarkan atribut jasa pelayanan yang diharapkan oleh mahasiswa adalah : ketepatan waktu dan kesesuaian jadwal, asisten bengkel harus mempunyai keahlian atau pengalaman di bengkel, memberikan pelatihan tambahan untuk asisten bengkel, penilaian terbuka dan mudah diakses, disediakan kotak kritik dan saran, dibuatkan form peminjaman alat, peningkatan kemampuan dan daya tanggap asisten bengkel, pembelian alat dan bahan untuk praktik, disediakan tempat sampah di bengkel, disediakan alat-alat kebersihan di bengkel, mahasiswa diwajibkan untuk membersihkan bengkel setelah selesai praktik, ruangan bengkel dengan pencahayaan dan sirkulasi udara yang baik, penilaian performa kerja (per tahun).

Pihak bengkel PUM diharapkan dapat melakukan pengembangan pelayanan bengkel dengan memperhatikan urutan prioritas berdasarkan hasil pengolahan dan analisis Quality Function Deployment (QFD) agar sesuai dengan harapan dan keinginan mahasiswa PUM. Untuk meningkatkan kepuasan konsumen (mahasiswa) maka pelayanan juga perlu ditingkatkan dengan peningkatan dan perbaikan kualitas SDM seperti pelatihan sebagai penunjang kemampuan asisten bengkel menangani masalah di bengkel PUM.

Tabel 8. Normalisasi raw weight

\begin{tabular}{clc}
\hline No & \multicolumn{1}{c}{ Kebutuhan Konsumen } & $\begin{array}{c}\text { Normalized } \\
\text { Raw Weight }\end{array}$ \\
\hline 1 & Jadwal praktik sesuai dengan waktu & 0,0589 \\
\hline 2 & Asisten bengkel membantu dalam menyelesaikan masalah & 0,0736 \\
\hline 3 & Penilaian didokumentasikan dengan baik & 0,0491 \\
\hline 4 & Penilaian akurat dan terbuka bagi praktikan & 0,0589 \\
\hline 5 & Asisten bengkel mudah ditemui dan tepat waktu & 0,0588 \\
\hline 6 & Asisten bengkel memberikan informasi yang tepat mengenai tata cara dan penilaian praktik & 0,0471 \\
\hline 7 & Di bengkel telah tersedia kotak pengaduan/keluhan & 0,0589 \\
\hline 8 & Administrasi penggunaan fasilitas bengkel mudah dan transparan & 0,0736 \\
\hline 9 & Asisten bengkel memiliki pengetahuan dan mampu menjawab praktikan & 0,0589 \\
\hline 10 & Asisten bengkel dapat menciptakan rasa aman kepada pratikan selama praktik berlangsung & 0,0736 \\
\hline 11 & Asisten bengkel mempunyai ketrampilan yang sangat memuaskan dalam memberikan pelayanan & 0,0588 \\
\hline & kepada pengguna layanan (mahasiswa) & 0,0589 \\
\hline 12 & Asisten bengkel memberikan perhatian kepda praktikan & 0,0589 \\
\hline 13 & Asisten bengkel sungguh-sungguh mengutamakan kepentingan praktikan & 0,0471 \\
\hline 14 & Jam operasional bengkel memberikan kemudahan bagi praktikan & 0,0589 \\
\hline 15 & Bengkel memiliki peralatan yang cukup lengkap dan mutakhir & 0,0471 \\
\hline 16 & Ruangan bengkel cukup luas, nyaman, dan bersih & 0,0589 \\
\hline 17 & Jumlah peralatan di bengkel cukup bagi pengguna layanan & 0,0589 \\
\hline 18 & Asisten bengkel berpenampilan rapi dan profesional & \\
\hline
\end{tabular}

Tabel 9. Kepentingan teknik

\begin{tabular}{cl}
\hline No & \multicolumn{1}{c}{ Kepentingan Teknik } \\
\hline 1 & Ketepatan waktu dan kesesuaian jadwal \\
\hline 2 & Asisten bengkel harus mempunyai keahlian/pengalaman di bengkel \\
\hline 3 & Memberikan pelatihan tambahan untuk asisten bengkel \\
\hline 4 & Penilaian terbuka, mudah diakses \\
\hline 5 & Disediakan kotak kritik dan saran \\
\hline 6 & Dibuatkan form peminjaman alat \\
\hline 7 & Peningkatan kemampuan dan daya tanggap asisten bengkel \\
\hline 8 & Pembelian alat dan bahan untuk praktik \\
\hline 9 & Disediakan tempat sampah di bengkel \\
\hline 10 & Disediakan alat-alat kebersihan di bengkel \\
\hline 11 & Mahasiswa diwajibkan untuk membersihkan bengkel setelah selesai praktik \\
\hline 12 & Ruangan bengkel dengan pencahayaan dan sirkulasi udara yang baik \\
\hline 13 & Penilaian performa kerja (per tahun) \\
\hline
\end{tabular}


Perlunya pembelian alat bengkel PUM agar mahasiswa bisa praktik sesuai dengan pembelajaran dan tidak berebutan pada saat praktik karena kurangnya alat.

\section{DAFTAR PUSTAKA}

Andreassen, T. W. (1994). Satisfaction, loyalty and reputation as indicators of customer orientation in the public sector. International Journal of Public Sector Management, 7(2), 16-34.

Baheramsyah. (2012). Identifikasi Dan Evaluasi Tingkat Kualitas Pelayanan Jasa Pendidikan Sekolah Menengah Atas (SMA) XYZ (Skripsi). Jakarta.

Bangun, A., Ginting, R., \& Tarigan, U. (2013). Analisis Kualitas Pelayanan Jasa Pendidikan dengan Menggunakan Quality Function Deployment di Jurusan Akuntansi Xyz. Jurnal Teknik Industri USU, 3(1).

Desiawan, V. A. (2010). Penerapan Quality Function Deployment dengan Mengadopsi Penggabungan Metode Service Quality dan Kano Model dalam Upaya Meningkatkan Kualitas Layanan pada Bengkel Resmi ATPM. Tesis tidak diterbitkan. Jakarta: Program Magister Teknik Industri ....

Hasanah, U. (2007). Penerapan Konsep Quality Function Deployment (QFD) dalam Meningkatkan Kualitas dan Mengembangkan Produk Sepeda Motor Honda Karisma 125D. Kepuasan Terhadap Konsumen.
Hidayat, A. (2012). Analisis Kepuasan Mahasiswa terhadap Proses Belajar Mengajar Di Jurusan Kemaritiman Politeknik Negeri Samarinda. JURNAL EKSIS, 8(1), 20602065.

Jaiswal, E. S. (2012). A case study on quality function deployment (QFD). IOSR Journal of Mechanical and Civil Engineering (IOSRJMCE), 3(6), 27-35.

Palmer, K. (2012). Voice of Customers. USA: Little Brown.

Rai, A. (2010). Metode-Metode Untuk Penilaian Kinerja. Surabaya: UNAIR.

Revelle, J. B., Moran, J. W., \& Cox, C. A. (1998). The QFD handbook. John Wiley \& Sons.

Rheza, K. P. (2014). ANALISIS KUALITAS PELAYANAN JASA DENGAN METODE SERVQUAL DAN QUALITY FUNCTION DEPLOYMENT (QFD)(STUDI KASUS PADA LABORATORIUM PEMROGRAMAN KOMPUTER TEKNIK INDUSTRI UPN "VETERAN" JATIM). UPN" VETERAN" JAWA TIMUR.

Widarman, A. (2016). USULAN RANCANGAN PENINGKATAN KUALITAS PELAYANAN DALAM PENYELENGGARAAN PENDIDIKAN DENGAN PENDEKATAN MODEL INTEGRASI SERVQUAL, KANO DAN QFD. UNPAS.

Wijaya, T. (2011). Manajemen kualitas jasa. Jakarta: PT. Indeks. 


\section{LAMPIRAN}

Tabel 10. Penentuan prioritas

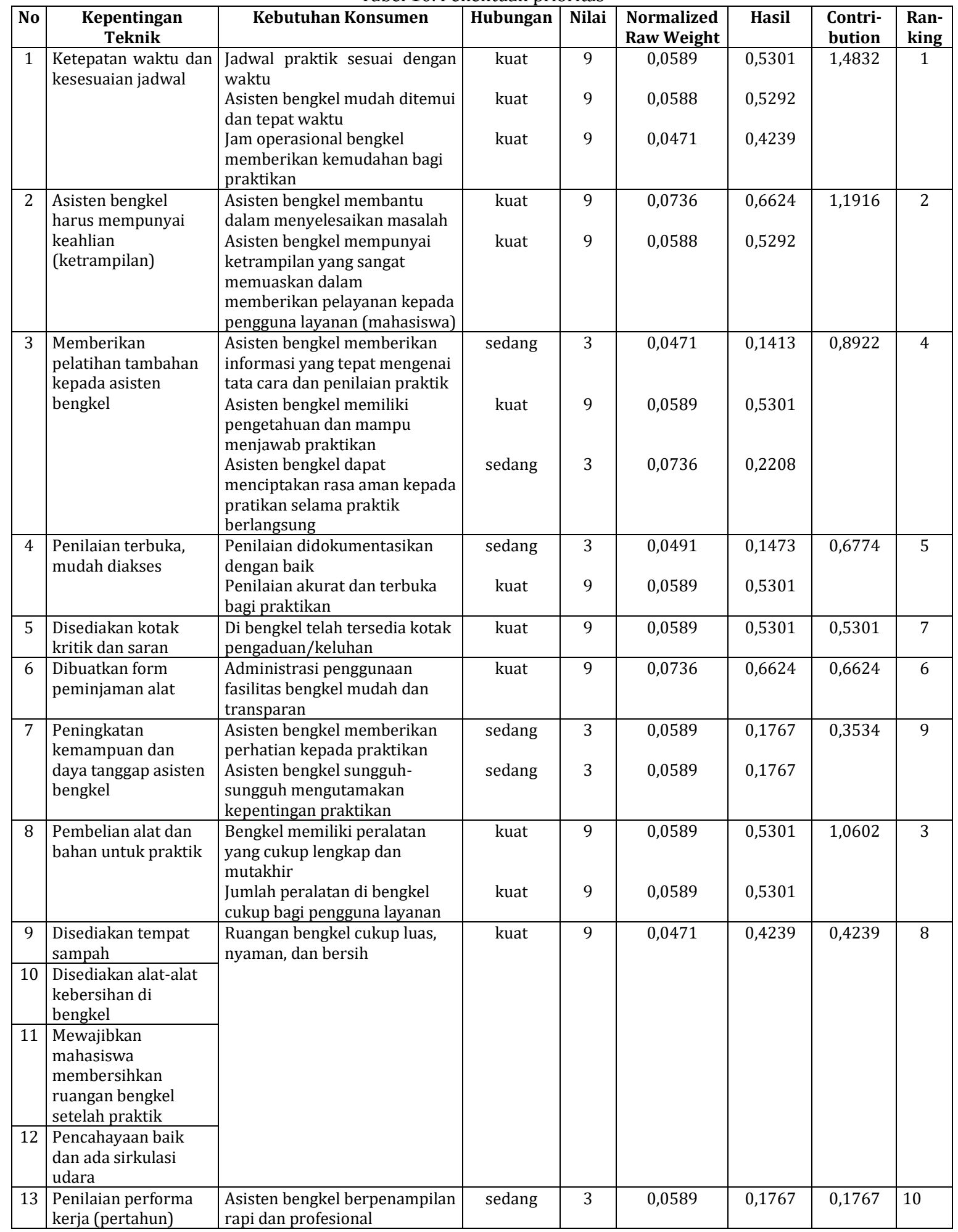

